Gut, 1981, 22, 744-751

\title{
Peripheral, mucosal, and tumour-infiltrating components of cellular immunity in cancer of the large bowel
}

\author{
P W BLAND, * D C BRITTON, E R RICHENS, \\ A N D J V P LE D G E \\ From the Department of Clinical Investigation, Royal United Hospital, Bath, and the \\ Pharmacology Group, University of Bath, Bath
}

\begin{abstract}
SUMMARY A reliable technique has been devised for the preparation of colorectal tumourinfiltrating lymphocytes (TIL). The immune capacity of these lymphocytes has been assessed in vitro and compared with that of lymphocytes infiltrating the lamina propria of adjacent normal mucosa (LPL) and with autologous peripheral blood lymphocytes (PBL). Assay of natural killer (NK) cell function revealed the absence of such activity in TIL and LPL despite the presence of normal levels in PBL. Antibody-dependent (K cell) cytotoxic activity was also absent in TIL and LPL. Both TIL and LPL showed significant mitogen-induced cytotoxic responses, although higher levels were detected in PBL. Tumour-infiltrating lymphocytes revealed depressed levels of spontaneous DNA synthesis, but mitogen stimulation of TIL was equivalent to that of LPL. T-cell proportions in TIL preparations were equivalent to those in PBL, but LPL comprised significantly fewer $\mathrm{T}$ cells.
\end{abstract}

The emergence in recent years of techniques for the isolation of lymphoid components from intestinal mucosa ${ }^{1-5}$ has resulted in the partial characterisation of these cells in terms of surface receptors and functional status determined in in vitro assays.

Because of the apparent inability of host defence mechanisms effectively to recognise and destroy the neoplastic cells of established solid tumours, despite infiltration of the tumours by host immune components, the functional capacity of these tumour-infiltrating lymphocytes (TIL) is of great interest. Almost invariably, however, TIL function has been assessed in relation to functional parameters assayed in autologous peripheral blood lymphocytes (PBL) or in lymph nodes draining the tumour. Investigations of lymphoid cell ecotaxis between blood, lymph node, and intestinal lamina

*Present address and address for reprints: Gastroenterology Laboratory, Wayne State University School of Medicine, Gordon $\mathbf{H}$ Scott Hall of Basic Medical Sciences, 540, East Canfield Avenue, Detroit, Michigan 48201, USA.

Received for publication 19 March 1981 propria" suggest that these compartments differ in their transient lymphocyte populations. In the case of large bowel adenocarcinoma, therefore, it is more relevant to compare TIL function with that of lymphocytes infiltrating the tissue of tumour origin-that is, lymphocytes infiltrating normal large bowel lamina propria (LPL).

We have isolated TIL from large bowel adenocarcinomata and LPL from adjacent histologically normal lamina propria using identical techniques. In vitro cytotoxic and blastogenic assays performed on these two populations and on autologous PBL revealed marked differences between peripheral and intestinal lymphocyte populations but smaller distinctions between LPL and TIL, suggesting that tumour modulation of TIL may be more subtle than previous reports suggest.

\section{Methods}

P A T I E N T S

A series of 24 patients (15 male, nine female), with ages ranging from 47 years to 87 years (mean 72 years), undergoing surgical resection of large bowel adenocarcinomata (five caecum, one ascend- 
ing colon, one descending colon, 10 sigmoid colon, seven rectum) was studied. None of the patients was receiving radiation or cytotoxic chemotherapy.

M E D I A

Eagle's Minimum Essential Medium (EMEM), Eagle's Minimum Essential Medium modified for suspension cultures (MEMS), and RPMI 1640 medium (RPMI) were obtained as $\times 10$ concentrates from Flow Laboratories, Irvine, Scotland, and were routinely supplemented at single strength with the following: $10 \%$ heat-inactivated fetal calf serum (FCS, Flow Laboratories) or $10 \%$ heatinactivated autologous plasma (AP); $20 \mathrm{mM}$ HEPES; $4.5 \mathrm{mM}$ sodium bicarbonate; $2 \mathrm{mM}$ L-glutamine; $40 \mu \mathrm{g} / \mathrm{ml}$ gentamicin, and 0.125 $\mu \mathrm{g} / \mathrm{ml}$ amphotericin B (Fungizone, Squibb). Phosphate buffered saline (PBS) was free of calcium and magnesium ions.

\section{T I S S U E S}

Twenty to 30 millilitres of heparinised blood was obtained from patients two to 24 hours before surgery and PBL were isolated by density gradient centrifugation over Ficoll-Triosil. These lymphocytes were thrice washed in RPMI before inclusion in assays.

Representative segments of tumour and normal mucosa were transferred to ice-cold EMEM immediately after resection and were processed within 30 minutes. LPL were isolated as previously described. ${ }^{7}$ Briefly, 1-5 g mucosa was dissected free of submucosa, washed extensively, cut into small sections, and incubated sequentially in $50 \mathrm{ml}$ PBS containing $1 \mathrm{mM}$ DL-dithiothreitol (DTT, Sigma) for 15 minutes at room temperature to remove mucus; $50 \mathrm{ml}$ PBS containing $0.75 \mathrm{mM}$ disodium EDTA for 90 minutes at $37^{\circ} \mathrm{C}$ to dissociate epithelial cells; and $50 \mathrm{ml}$ EMEM containing 20 units $/ \mathrm{ml}$ purified collagenase (type VI, Sigma or CLSPA, Worthington), and $25 \mu \mathrm{g} / \mathrm{ml}$ (approximately 50-65 units $/ \mathrm{ml}$ ) deoxyribonuclease 1 (Worthington) overnight at $37^{\circ} \mathrm{C}$ to dissociate lamina propria components. The resultant cell suspension was filtered twice through looselypacked nylon wool columns to remove remaining cell aggregates and thrice washed in MEMS. Tumour tissue was simultaneously treated in an identical fashion to release TIL.

After assessment of mononuclear cell viability ( $0.1 \%$ Trypan blue), LPL and TIL were separated from other cell types on isokinetic gradients of $2.7 \%$ to $5.4 \%$ Ficoll (Pharmacia) in MEMS constructed exactly as described. ${ }^{7}$ Ten to 20 million total cells in $3 \mathrm{ml}$ MEMS were layered over each gradient. Gradients were centrifuged at $98 \mathrm{~g}$, measured at the sample gradient interface, for 14 minutes at $4^{\circ} \mathrm{C}$. After centrifugation, the LPL or TIL enriched fraction was removed (see Results), thrice washed in RPMI, and included in the assays as described below.

\section{A S S A Y S \\ E-rosettes}

Proportions of lymphocytes in PBL, LPL, and TIL populations forming E-rosettes with 2aminoethylisothiouronium-coated sheep red blood cells (AET-SRBC) were determined using the method of Kaplan and Clark. ${ }^{8}$

\section{CYTOTOXIC ASSAYS}

Spontaneous cell-mediated cytotoxicity (SCMC), antibody-dependent cell-mediated cytotoxicity (ADCC), and mitogen-induced cell-mediated cytotoxicity (MICC) of PBL, LPL, and TIL populations were assayed in ${ }^{51} \mathrm{Cr}$-release assays using Chang liver cells (CLC) as targets. In four patients SCMC and ADCC were additionally assayed using respectively K562 (an erythroblastoid cell line) and chicken red blood cells (CRBC) as targets. Target cells $\left(10^{6}\right)$ were labelled with $100 \mu \mathrm{Ci}$ sodium chromate- ${ }^{51} \mathrm{Cr}(250-500 \mu \mathrm{Ci} / \mu \mathrm{g}$, Radiochemical Centre, Amersham) for one hour at $37^{\circ} \mathrm{C}$, washed three times, and adjusted to $10^{5}$ cells $/ \mathrm{ml}$ in RPMI. Assays were carried out in triplicate in plastic tubes. To each experimental tube was added $100 \mu \mathrm{l}$ labelled target cells $\left(10^{4}\right.$ cells $) ; 100 \mu 1$ lymphocyte. suspension $\left(2.5 \times 10^{5}\right.$ cells, or, in the case of K562 targets, $5.0 \times 10^{8}$ cells); and $100 \mu \mathrm{l}$ rabbit antitarget cell antiserum (ADCC assays: $10^{-3}$ and $10^{-4}$ dilutions of anti-CLC or $10^{-2}$ and $10^{-3}$ dilutions of anti-CRBC), or $100 \mu \mathrm{l}$ RPMI containing purified phytohaemagglutinin (PHA, Wellcome: MICC assays, final concentration $1 \mu \mathrm{g} / \mathrm{ml}$ ), or RPMI alone in SCMC assays to give a final incubation volume in all assays of $400 \mu 1$. Tubes were capped and incubated at $37^{\circ} \mathrm{C}$ for 18 hours (except SCMC assays using $\mathrm{K} 562$ targets which were incubated for four hours. Spontaneous ${ }^{51} \mathrm{Cr}$ release (SR) was estimated in tubes containing target cells and RPMI only. Maximum release (MR) was estimated by detergent lysis of the target cells. After incubation the tubes were centrifuged at $150 \mathrm{~g}$ for five minutes; $200 \mu \mathrm{l}$ of each culture supernatant was withdrawn and counted with the residual supernatant plus cell pellet in a gamma counter. Percentage specific ${ }^{51} \mathrm{Cr}$ release was calculated as follows: 
Percentage ${ }^{51} \mathrm{Cr}$ release $=$

$$
\frac{\text { Supernatant } \mathrm{cpm} \times 2}{\text { Supernatant } \mathrm{cpm}+\text { Residual cpm }}
$$

Percentage Specific ${ }^{i 1} \mathrm{Cr}$ release $=$

$$
\frac{\text { Test release }-\mathrm{SR}}{\mathrm{MR}-\mathrm{SR}}
$$

\section{Blastogenic assay}

All manipulations and incubations were carried out in RPMI $+10 \%$ AP. One hundred microlitre aliquots containing $10^{n}$ lymphocytes were pipetted into round-bottom wells of a microtitre plate (Sterilin). Purified PHA was added to the wells in $100 \mu \mathrm{l}$ volumes to give final concentrations of 0 , 1,5 and $10 \mu \mathrm{g} / \mathrm{ml}$. The plate was covered and incubated at $37^{\circ} \mathrm{C}$ for 72 hours in an atmosphere of $95 \%$ air, $5 \% \mathrm{CO}_{2}$. All cultures were then pulsed for four hours with $1 \mu \mathrm{Ci}{ }^{3} \mathrm{H}$-thymidine (specific activity $5 \mathrm{Ci} / \mathrm{mmol}$, Radiochemical Centre, Amersham). Cultures were harvested onto glass fibre discs (Whatman, GF/C) using an Ilacon cell harvester. After drying, the discs were counted for activity in a toluene-based scintillant.

\section{Statistical analysis}

Because of variations in the number of each type of lymphocyte population measured, it was not possible to perform all assays with autologous PBL, LPL, and TIL. Results from all patients in each group were pooled and significance was determined by application of the Mann-Whitney U test.

\section{Results}

I S O K I N E T I C GR A D I E N T S

Because of the heterogeneity of cell types released after tumour digestion, it was necessary to subject isokinetic gradients to a higher centrifugal force $(98 g)$ than previously reported ${ }^{7}$ for the preparation of LPL from normal mucosa. The efficiency and reproducibility of lymphocyte purification on these gradients was assessed in two separate experiments using PBL. A total of $16 \times 10^{4}$ cells $\left(15 \times 10^{6}\right.$ mononuclear $+10^{i}$ erythrocytes $)$ in $3 \mathrm{ml}$ MEMS was layered over each of two identical isokinetic gradients. After centrifugation at $98 \mathrm{~g}$ for 14 minutes at $4^{\circ} \mathrm{C}$, the sample volume of $3 \mathrm{ml}$ was removed, followed by successive $4 \mathrm{ml}$ fractions. Total and differential cell counts were performed on each gradient fraction. Mononuclear cell recoveries from the gradient fractions are depicted in Fig. 1. Of the $15 \times 10^{4 i}$ mononuclear

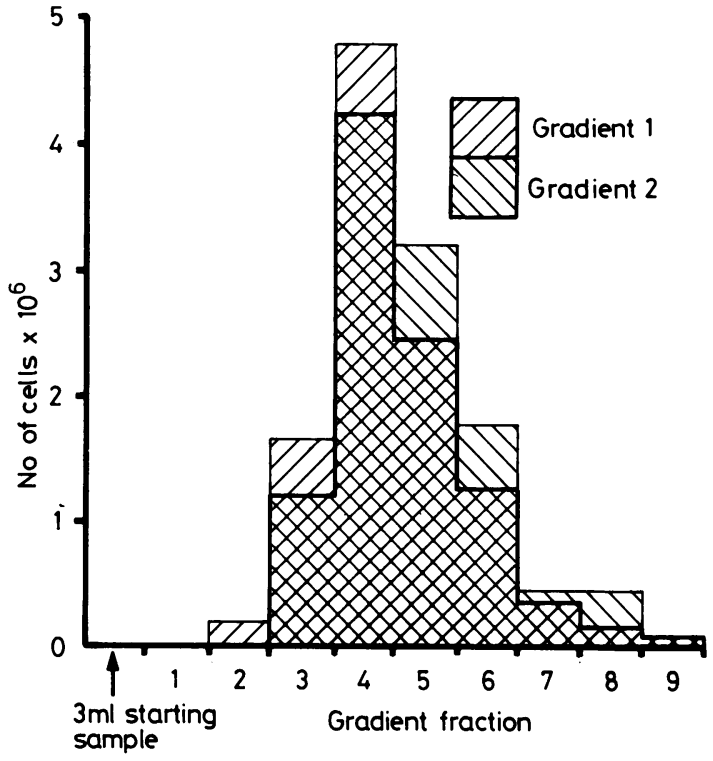

Fig. 1 The distribution of mononuclear cells recovered from two identical isokinetic gradients. Fifteen million peripheral blood cells were applied to each gradient and the gradients were centrifuged at $98 \mathrm{~g}$ for 14 minutes at $4^{\circ} \mathrm{C}$. Each gradient fraction measured $4 \mathrm{ml}$. Accumulated recoveries and differential counts are given in the text. $\mathbb{Z}:$ gradient 1 $\mathbb{N}$ : gradient 2 .

cells layered onto gradient $1,77 \%\left(11.5 \times 10^{6}\right)$ were recovered, $89 \%\left(10 \cdot 2 \times 10^{\prime \prime}\right)$ of these sedimenting into gradient fractions $3,4,5$ and 6 . Recovery from gradient 2 was very similar: $79 \%\left(11.8 \times 10^{\prime \prime}\right)$ total recovery with $89 \%\left(10.5 \times 10^{6}\right)$ recovered from the modal population. The combined differential count for fractions $3,4,5$. and 6 was $94 \%$ lymphocytes, $6 \%$ monocytes, $\ll 1 \%$ polymorphs. Receptors for SRBC, and spontaneous and antibody-dependent cytotoxic responses were unaffected by isokinetic gradient treatment. Responses to PHA were reduced by approximately $10 \%$ after isokinetic gradient treatment, but spontaneous DNA incorporation remained unaffected.

The portion of the gradient represented by fractions $3,4,5$, and 6 in the experiments described above was therefore recovered after LPL and TIL preparation and treated as the modal population of these lymphocytes. After such treatment of tumour digests, tumour cells sedimented to the gradient-cushion interface and contamination of TIL by tumour cells was always less than $1 \%$. 


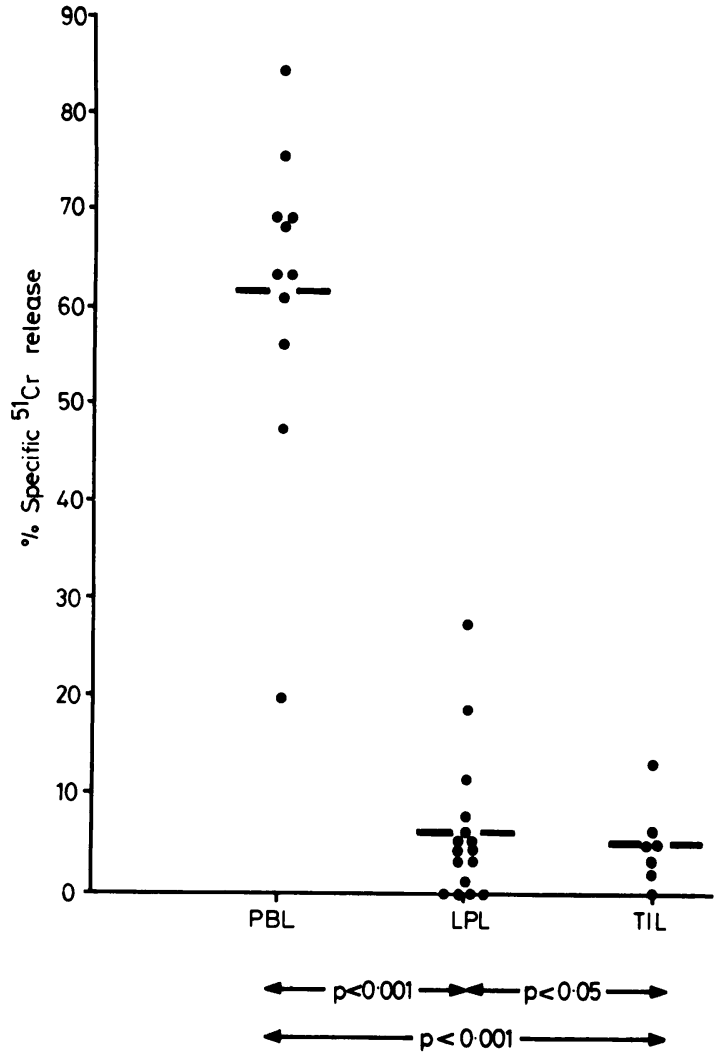

Fig. 2 Antibody-dependent cell-mediated cytotoxicity $(A D C C)$ of $P B L, L P L$, and $T I L$ to $"$ "Cr-labelled Chang liver cells. Effector: target cell ratio, 25:1; incubation time, 18 hours, anti-target cell antiserum dilutions, 1:1000 and 1:10 000. Each point represents the mean specific "il $\mathrm{C} r$ release from triplicate assays performed with effector cells from a single patient. Horizontal hars represent the mean for each group.

C Y TOTOXIC RESPONSES

The ADCC activity of PBL, LPL, and TIL populations to CLC targets is shown in Fig. 2. It is clear that, of the three lymphocyte populations, only PBL were capable of mediating ADCC. Similarly, in four individuals tested for ADCC with CRBC targets, only PBL were reactive (mean $56.9 \%$, range $47.0 \%$ to $62.8 \%$ ). LPL were unreactive (mean $2.7 \%$, range $0 \%$ to $9.8 \%$ ) and TIL were not tested in this assay. Figure 3 shows that LPL and TIL were similarly unreactive in the NK cell-mediated SCMC assay with CLC targets, whereas $\mathrm{PBL}$ induced a mean specific ${ }^{1 .} \mathrm{Cr}$ release of $31.7 \%$ from the target cells. The low SCMC activity of LPL was confirmed in assays using K562 target cells with lymphocytes from three patients (PBL, mean $39.6 \%$, range $17 \cdot 4 \%$ $57.5 \%$; LPL, mean $9.1 \%$, range $1.5 \%-18.9 \%$ ).

Contrasting with their low levels of reactivity in SCMC and ADCC assays, both LPL and TIL showed significant levels of responsiveness in the MICC assay (Fig. 4). Their responses did not differ in this assay but both populations showed significantly less activity than PBL.

The extent of variability in all three cytotoxic parameters assessed in PBL was considerably greater than that normally experienced in $\mathrm{PBL}$ from healthy controls (not shown), although no direct correlation with any recorded disease parameters could be found to account for this variability.

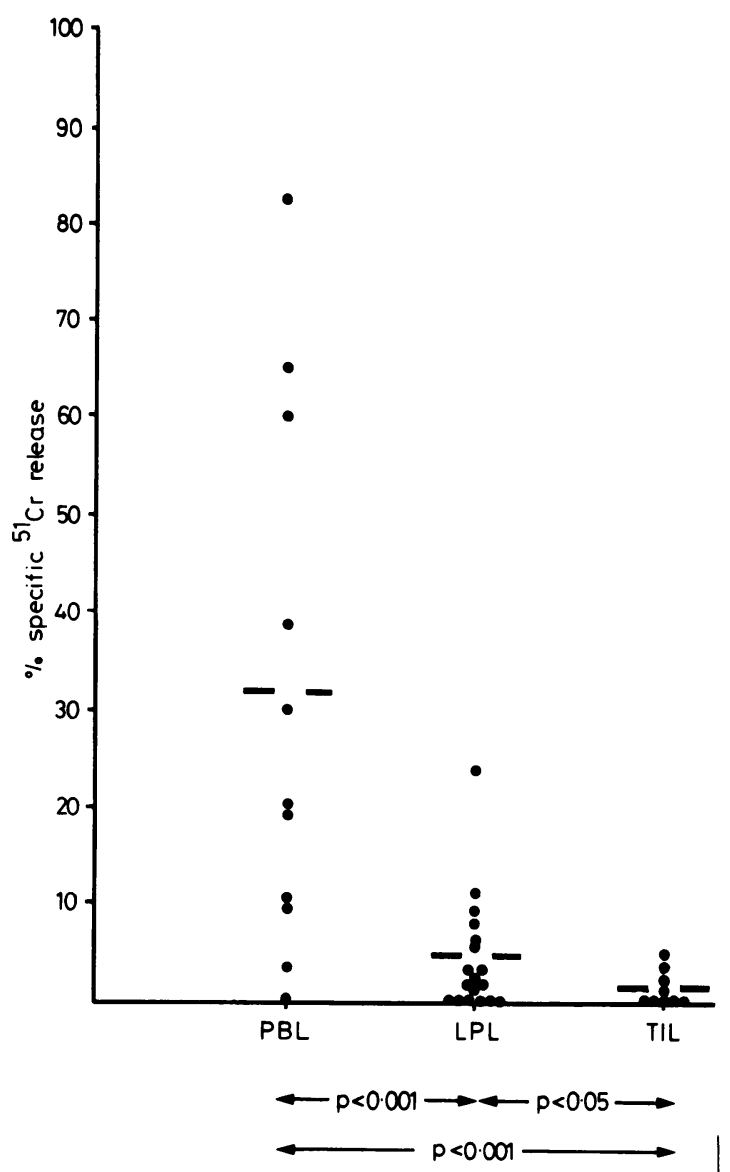

Fig. 3 Spontaneous cell-mediated (ytotoxicity (SCMC) of PBL. LPL. and TIL to "ICr-labelled Chang liver cells. Effector: target cell ratio, 25:1; incubation time. 18 hours. Each point represents the mean specific ${ }^{\circ 1} \mathrm{Cr}$ release from triplicate assay's performed with effector cells from a single patient. Horizontal hars represent the mean for each group. 


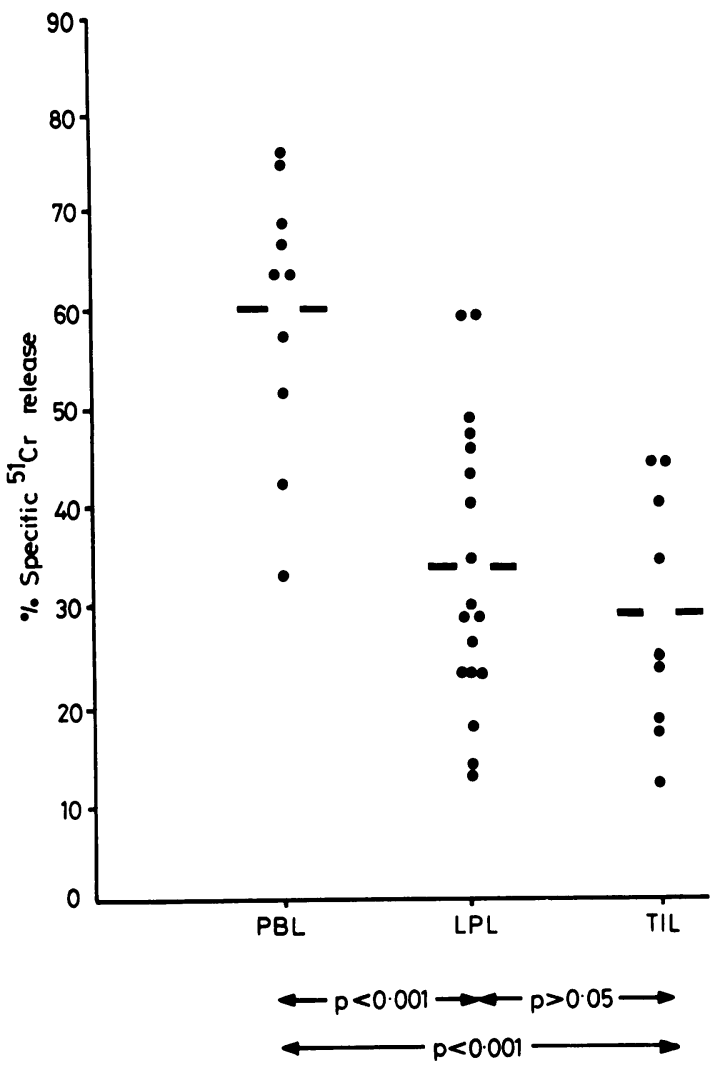

Fig 4 Mitogen-induced cell-mediated cytotoxicity (MICC) of PBL, LPL, and TIL to " ${ }^{51}$ r-labelled Chang liver cells. Effector: target cell ratio, 25:1; incubation time 18 hours; PHA concentration $1 \mu \mathrm{g} / \mathrm{ml}$. Each point represents the mean specific ${ }^{51} \mathrm{Cr}$ release from triplicate assays performed with effector cells from a single patient. Horizontal hars represent the mean for each group.

E - R O S E T T E S

Percentages of E-rosetting cells (Fig. 5) in PBL and TIL were not significantly different (means: $\mathrm{PBL}=67 \%$; TIL $=64 \%$ ), but LPL comprised significantly fewer $\mathrm{T}$ cells (mean, $51 \%$ ).

B L A S TOG EN I C RES PON SES

Spontaneous rates of DNA synthesis in the three lymphocyte populations, measured by incorporation of ${ }^{3} \mathrm{H}$-thymidine, are shown in Fig. 6 . Incorporation into TIL was significantly less than into either PBL or LPL. Incorporation into these latter two populations did not differ significantly, although greater variation was evident in the values of $L P L$.

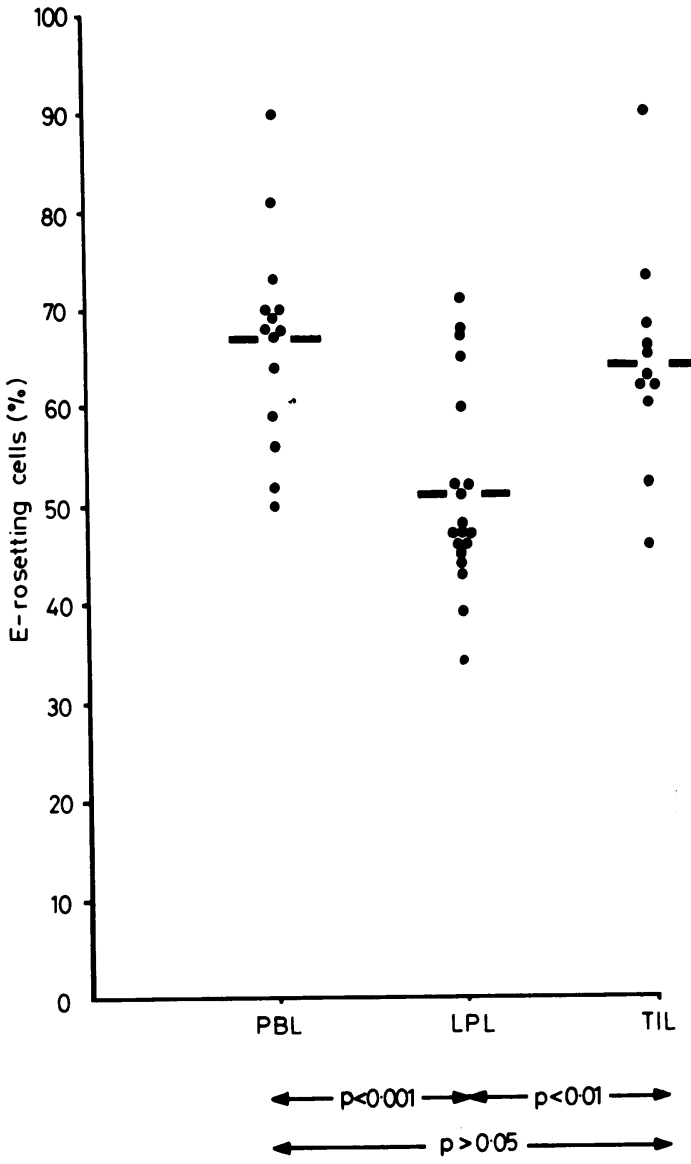

Fig. 5 Percentages of PBL, LPL, and TIL forming rosettes with $A E T$-coated $S R B C$. Each point represents the mean of triplicate assays performed with cells from a single patient. Horizontal bars represent the mean for each group.

Blast transformation by $\mathrm{PBL}$ in response to PHA was found to be greater at all three concentrations of the mitogen than that induced in LPL or TIL (Fig. 7). This difference between peripheral and local lymphocyte responsiveness is significant even when the effect of preparative procedure is taken into account. In addition, $\mathrm{PBL}$ responded maximally at $5 \mu \mathrm{g} \mathrm{PHA} / \mathrm{ml}$, whereas both LPL and TIL showed declining responses at concentrations of PHA greater than $1 \mu \mathrm{g} / \mathrm{ml}$. There was no significant difference between LPL and TIL responses at any of the PHA concentrations used. 


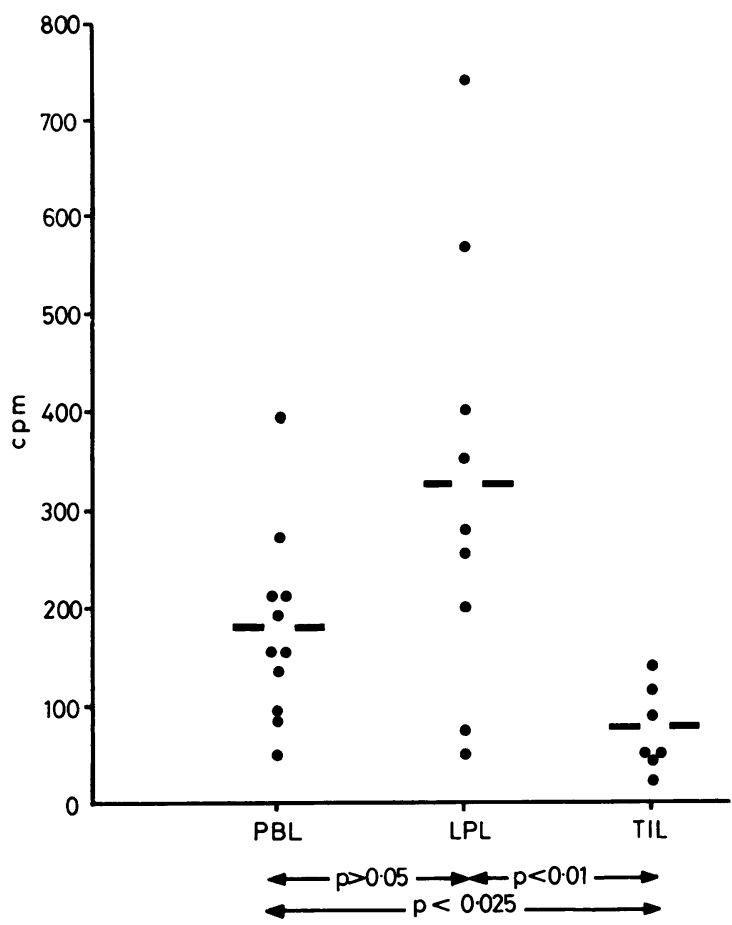

Fig. 6 Spontaneous incorporation of 'H-thymidine into $P B L, L P L$, and TIL after 72 hours' incubation at $37^{\circ} \mathrm{C}$. Each point represents the mean of three or more assays performed with cells from a single patient. Horizontal bars represent the mean for each group.

\section{Discussion}

There are numerous reports in recent literature of attempts to demonstrate K-cell activity in the gut mucosa, stimulated largely by histological evidence' ${ }^{9}$ of Fc receptor-bearing cells in the colonic lamina propria and by the proposal ${ }^{10}$ of an antibody-dependent cytotoxic mechanism directed against colonic epithelial cells as the pathogenetic factor in inflammatory bowel disease. Isolated LPL, however, have been shown by several investigators to possess low ADCC activity. ${ }^{11-14}$ More recently it has been proposed ${ }^{15}{ }^{16}$ that the K-cell activity of isolated LPL depends upon the target cell used in the assay, erythrocyte targets showing greater susceptibility to lysis than cell lines. Fiocchi et al. ${ }^{14}$ on the other hand, found no evidence of LPL. Kcell induced lysis of $\mathrm{CRBC}$ in plaque or ${ }^{51} \mathrm{Cr}$ release assays. Our results, presented here, substantiate this latter view, that LPL do not mediate ADCC against cell line or erythrocyte targets. Fc

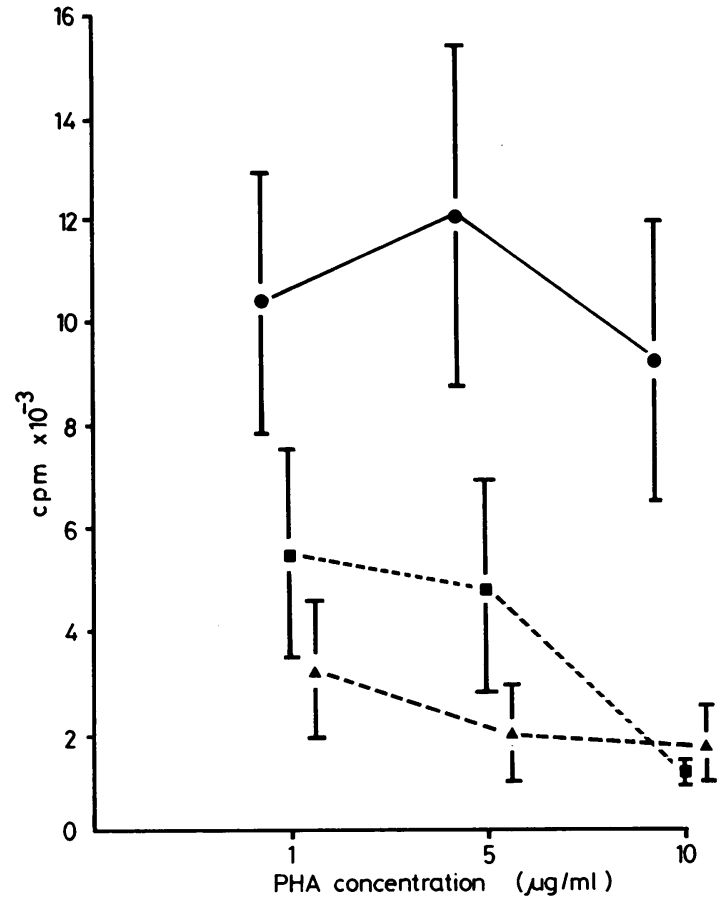

Fig. 7 The blastogenic response of PBL (๑), I.PI ( $\mathbf{\square})$, and TIL ( $\mathbf{\Delta})$ to three concentrations of $P H A$ in 72 hour incubations at $37^{\circ} \mathrm{C}$. Cultures were pulsed with $\mathrm{l} \mu \mathrm{Ci}$ : $\mathrm{H}$-thymidine four hours before termination. Each point represents the mean $\pm S E$ of three or more assays performed with cells from at least five patients. PHA $1 \mu \mathrm{g} / \mathrm{ml}:$ PBL vs $L P L$ : $\mathrm{P}>0.05 ; L P L$ vs $T I L: \mathrm{P}=0.245 ; P B L$ vs $T I L$ : $\mathrm{P}<0.025$. PHA $5 \mu \mathrm{g} / \mathrm{ml}:$ PBL vs $L P L ; \mathrm{P}<0.05: L P L$ v.s $T I L ; \mathrm{P}=0.183: P B L$ vs $T I L ; \mathrm{P}<0.025$. $\mathrm{PHA}$ $10 \mu \mathrm{g} / \mathrm{ml}: P B L$ vs $L P L ; \mathrm{P}<0.001: L P L$ vs $T I L$; $\mathrm{P}=0.357: P B L$ vs $T I L ; \mathrm{P}=0.067$.

receptor-bearing LPL have been reported as either comparable in number with those in $\mathrm{PBL}^{15}$ or completely absent. ${ }^{13}$ It has been suggested that ADCC may be dependent upon other unknown factors in addition to possession by the effector cell of $\mathrm{Fc}$ receptors. ${ }^{15}$ Indeed, we have occasionally encountered significant ADCC activity in large bowel LPL isolated from resected specimens in various disease states, suggesting the need for a carefully controlled study correlating lytic ability with possible modulating factors-for example, blocking of receptors by locally-produced antibody or antigen/antibody complexes, and suppressor cell activity.

The lack of LPL responsiveness in NK-mediated SCMC paralleled the low antibody-dependent cytotoxic ability of these cells and agrees with previous 
reports. ${ }^{45^{-17}}$ This also suggests a deficit in Fc receptor availability in the lamina propria or the modulation of effector cells by unknown factors in the mucosal environment.

Assay of natural and antibody-dependent killing by TIL revealed that these mechanisms are either absent or suppressed within large bowel tumours. Other workers ${ }^{1 \times 19}$ have shown that K562 target cells are similarly resistant to lysis by TIL isolated from lung and breast tumours despite the presence of $\mathrm{Fc}$ receptor-bearing cells in isolates. Further, inhibition of NK activity by co-culture of effector cells with adherent cell populations was demonstrated $^{19}$ and the possibility was raised of suppression of NK activity by prostaglandins secreted within the tumour milieu by macrophages and monocytes. If this suppressive mechanism exists in vivo in tumours, it may also be an important factor in $K$ and NK cell suppression within the normal bowel lamina propria. We have already shown ${ }^{7}$ that LPL $\mathrm{K}$ cell activity can be boosted by pre-treatment of the cells with a prostaglandin synthetase inhibitor. This could be an important mode of suppression in the gut lamina propria, particularly in inflammatory bowel disease where increased monocyte/ macrophage populations have been reported. ${ }^{20}$

The finding of significant MICC activity in LPL confirms previous reports ${ }^{45-1721}$ Although initially devised to assess polyclonal T-cell cytotoxicity, this assay is now thought to reflect both polyclonal and $\mathrm{Fc}$ receptor-bearing $\mathrm{T}$-cell components. ${ }^{22}$ It is interesting that, in the present study, MICC levels in TIL were not significantly different from levels in LPL despite the presence of a greater proportion of T-cells in TIL. This may indicate either that differences exist in the $\mathrm{T} \mu$ and $\mathrm{T} \gamma$ subpopulations ${ }^{23}$ infiltrating normal and malignant mucosa, or that TIL T-cell activity is depressed by some factor within the tumour milieu.

Spontaneous DNA synthesis by lymphocytes from normal mucosa did not differ from PBL values. In contrast, TIL showed little spontaneous incorporation of ${ }^{3} \mathrm{H}$-thymidine over 72 hours. The similarity of PBL and LPL values agrees with a previous report $^{3}$ by workers who isolated LPL using an enzymatic technique, but contrasts with a study" in which LPL were isolated by mechanical techniques and which showed reduced spontaneous activity in LPL compared with PBL. The possibility that mechanical isolation procedures can release metabolic inhibitors has already been discussed. ${ }^{7}$ Our results suggest that lymphocytes in peripheral blood and in the gut lamina propria exist, not unnaturally, in a state of activation induced by the readily accessible antigenic environment. The low rate of spontaneous DNA synthesis by TIL suggests either that these lymphocytes are sequestered from lumenal antigens, or that their ability to become activated is impaired by the tumour environment.

The impaired ability of LPL and TIL to respond to PHA, compared with the responsiveness of PBL, is a common finding. ${ }^{2}: 2.4$ That TIL transformation was equivalent in amplitude to LPL blast formation may indicate that, in spite of their low levels of spontaneous DNA synthesis, TIL are able to respond to antigenic stimulus, although not necessarily to tumour antigens. Indeed, it has been shown ${ }^{10}$ that although TIL from lung and breast tumours are reactive to PHA, they do not respond to autologous tumour antigens, despite the fact that PBL from the same patients showed responsiveness to both PHA and autologous tumour. The peripheral blood and gut-associated lymphocyte populations responded maximally to different concentrations of PHA. This may reflect differences in density and availability of cell membrane receptors for the mitogen between the two lymphocyte compartments.

In summary, the present work suggests that reports of depressed immune competence existing within tumours ought to be reassessed in terms of lymphocyte reactivity within the normal tissue of tumour origin, particularly in relation to tumours of mucosal surfaces. In the case of large bowel neoplasia, the availability of tissues representing the normal-adenoma-carcinoma transition enables observation of possible changes in lymphocyte character and function taking place during the development of malignancy. Such investigations are currently in progress using the methodology described above.

We wish to thank the surgical staffs of the Royal United Hospital and St Martin's Hospital, Bath, for their assistance. We are also grateful to the staff of the Photographic Department, Royal United Hospital, Bath, for reproduction of the Figures, and to Miss Rachel Humphreys for typing the manuscript. The work was supported by the Wessex Regional Health Authority.

\section{References}

${ }^{1}$ Rudzik O, Bienenstock J. Isolation and characteristics of gut mucosal lymphocytes. Lab Invest 1974; 30:260-6. 
${ }^{2}$ Clancy $R$. Isolation and kinetic characteristics of mucosal lymphocytes in Crohn's disease. Gastroenterology 1976; 70:177-80.

3Bull DM, Bookman MA. Isolation and functional characterisation of human intestinal mucosal lymphoid cells. J Clin Invest 1977; 59:966-74.

${ }^{4}$ Arnaud-Battandier F, Bundy BM, O’Neill M, Bienenstock J, Nelson DL. Cytotoxic activities of gut mucosal lymphoid cells in guinea-pigs. $J$ Immunol 1978; 121:1059-65.

5oodacre R, Davidson R, Singal D, Bienenstock J. Morphologic and functional characteristics of human intestinal lymphoid cells isolated by a mechanical technique. Gastroenterology 1979; 76:30()-8.

'ide Sousa M, Good RA. T- and B-cell populations in gut-associated lymphoid organs: arrangement, migration and function. In: Lipkin M, Good RA, eds. Gastrointestinal tract cancer. New York: Plenum Medical Book Company, 1978; 29-47.

${ }^{7}$ Bland PW, Richens ER, Britton DC, Lloyd JV. Isolation and purification of human large bowel mucosal lymphoid cells: effect of separation technique on functional characteristics. Gut 1979; 20: $1037-46$.

'Kaplan ME, Clark C. An improved rosetting assay for detection of human T-lymphocytes. J Immunol Methods 1974; 5:131-5.

9Strickland RG, Husby G, Black WC, Williams RC Jr. Peripheral blood and intestinal lymphocyte subpopulations in Crohn's disease. Gut 1975; 16:847-53.

${ }^{10}$ Stobo JD, Tomasi TB, Huizenga KA, Spencer RJ, Shorter RG. In vitro studies of inflammatory bowel disease. Surface receptors of the mononuclear cell required to lyse colonic epithelial cells. Gastroenterology 1976; 70:171-6.

"Bookman MA, Helms RA, Bull DM. Isolated human intestinal lymphoid cells: alterations in inflammatory bowel disease (IBD). (Abstract). Gastroenterology 1977; 72:1155.

${ }^{12}$ Clancy R, Pucci A. Absence of K-cells in human gut mucosa. Gut 1978; 19:273-6.

${ }^{13}$ Bookman MA, Bull DM. Characteristics of isolated intestinal mucosal lymphoid cells in inflammatory bowel disease. Gastroenterology 1979; 77:503-10.
${ }^{14}$ Fiocchi C, Battisto JR, Farmer RG. Gut mucosal lymphocytes in inflammatory bowel disease. Isolation and preliminary functional characterisation. Dig Dis Sci 1979; 24:705-17.

${ }^{15}$ MacDermott RP, Franklin GO, Jenkins KM, Kodner IJ, Nash GS, Weinrieb IJ. Human intestinal mononuclear cells. I. Investigation of antibody-dependent, lectin-induced and spontaneous cell-mediated cytotoxic capabilities. Gastroenterology 1980; 78:47-56.

${ }^{16}$ Chiba M, Shorter RG, Thayer WR, Bartnik W, Remine S. K-cell activity in lamina proprial lymphocytes from the human colon. Dig Dis Sci 1979; 24: 817-22.

1iFalchuk ZM, Barnhard E, Machado I. Human colonic lamina propria lymphocytes mediate mitogen-induced but not spontaneous cell-mediated cytotoxicity. (Abstract). Gastroenterology 1979; 76: 1129.

${ }^{18}$ Vose BM, Moore M. Suppressor cell activity of lymphocytes infiltrating human lung and breast tumours. Int J Cancer 1979; 24:579-85.

19 Vose BM. Natural killers in human cancer: activity of tumour-infiltrating and draining node lymphocytes. In: Herberman RB, ed. Natural cell-mediated immunity against tumours. New York: Academic Press, 1980.

${ }^{20}$ Meuret G, Bitzi A, Hammer B. Macrophage turnover in Crohn's disease and ulcerative colitis. Gastroenterology 1978; 74:501-3.

${ }^{21}$ Braden GL, Masters JT, Onderdonk AB, Falchuk ZM. Lamina propria lymphocytes mediate mitogeninduced cellular cytotoxicity in guinea-pigs with carageenan-induced colitis. (Abstract). Gastroenterology 1980; 78:1144.

${ }^{22}$ Bonavida B, Robins A, Saxon A. Lectin-dependent cellular cytotoxicity in man. Transplantation 1977; 23:261-70

${ }^{23}$ Cordier G, Samarut C, Revillard J-P. Contribution of lymphocytes bearing $F c \gamma$ receptors to PHAinduced cytotoxicity. Immunology 1978; 35:49-56.

${ }^{24}$ Mavligit GM, Jubert AV, Gutterman JU, McBride CM, Hersh EM. Immune reactivity of lymphoid tissues adjacent to carcinoma of the ascending colon. Surg Gynecol Obstet 1974; 139:409-12. 